\title{
FNTB wt Allele
}

National Cancer Institute

\section{Source}

National Cancer Institute. FNTB wt Allele. NCI Thesaurus. Code C52033.

Human FNTB wild-type allele is located within 14q23-q24 and is approximately $76 \mathrm{~kb}$ in length. This allele, which encodes protein farnesyltransferase beta subunit protein, plays a role in the post-translational modification of certain proteins via the addition of a farnesyl group. 